\title{
Gonadal Development and Tumor Formation at the Crossroads of Male and Female Sex Determination
}

\author{
M. Cools ${ }^{a}$ K.P. Wolffenbuttel ${ }^{b}$ S.L.S. Drop ${ }^{c}$ J.W. Oosterhuis ${ }^{d}$ L.H.J. Looijenga ${ }^{d}$ \\ a Division of Pediatric Endocrinology, Department of Pediatrics, University Hospital Ghent and Ghent University, \\ Ghent, Belgium; ${ }^{b}$ Department of Urology and ${ }^{\mathrm{C}}$ Division of Pediatric Endocrinology, Department of Pediatrics, \\ Sophia Children's Hospital and Erasmus Medical Center, and d Department of Pathology, Erasmus Medical Center, \\ Josephine Nefkens Institute, Rotterdam, The Netherlands
}

\section{Key Words}

Carcinoma in situ • Disorder of sex development •

Dysgerminoma - Germ cell tumor - Gonadal development • Gonadoblastoma

\begin{abstract}
Malignant germ cell tumor (GCT) formation is a well-known complication in the management of patients with a disorder of sex development (DSD). DSDs are defined as congenital conditions in which development of chromosomal, gonadal, or anatomical sex is atypical. DSD patients in whom the karyotype - at least at the gonadal level - contains (a part of) the $Y$ chromosome are at increased risk for neoplastic transformation of germ cells, leading to the development of the so-called 'type II germ cell tumors'. However, tumor risk in the various forms of DSD varies considerably between the different diagnostic groups. This contribution integrates our actual knowledge on the pathophysiology of tumor development in DSDs, recent findings on gonadal (mal)development in DSD patients, and possible correlations between the patient's phenotype and his/her risk for germ cell tumor development.

Copyright $\odot 2011$ S. Karger AG, Basel
\end{abstract}

(C) 2011 S. Karger AG, Basel

$1661-5425 / 11 / 0054-0167 \$ 38.00 / 0$

Fax +4161306 1234

E-Mail karger@karger.ch

www.karger.com
Accessible online at:

www.karger.com/sxd

\section{Normal Gonadal Development}

Phenotypic sexual differentiation is the result of 3 consecutive processes: stabilization and development of the primitive urogenital ridge, differentiation of the bipotential gonad into either a testis or an ovary, referred to as (gonadal) sex determination, and finally intact hormone production and action by the differentiated gonad [Grumbach et al., 2003] (fig. 1). In the last decades, several genes have been identified mostly in mice that are involved in this process at one or more levels. Steroidogenic factor 1 (Sf1, encoded by Nr5a1), Wt1 (Wilms' tumor 1), Lhx9 (LIM homeobox protein 9), and Emx2 (empty spiracles homolog 2) are important for stabilization and development of the urogenital ridge [Wilhelm and Koopman, 2006; Wilhelm et al., 2007a; Lin and Achermann, 2008]. At this stage, a balanced antagonism of male (Sox9, SRYbox containing gene 9) and female (Rspo1, R-spondin homolog) opposing signals, at very low expression levels, has been proposed to keep the gonad in a bipotential stage [Schlessinger et al., 2010]. In males, testis development is initiated around 10.5 days post coitum (dpc) by Sry (sexdetermining region of chromosome $\mathrm{Y}$ ) expression from the Y chromosome [Koopman et al., 1991]. However, at present, Sox9 rather than Sry is considered to be the 
Fig. 1. Schematic overview of gonadal development and sexual differentiation.

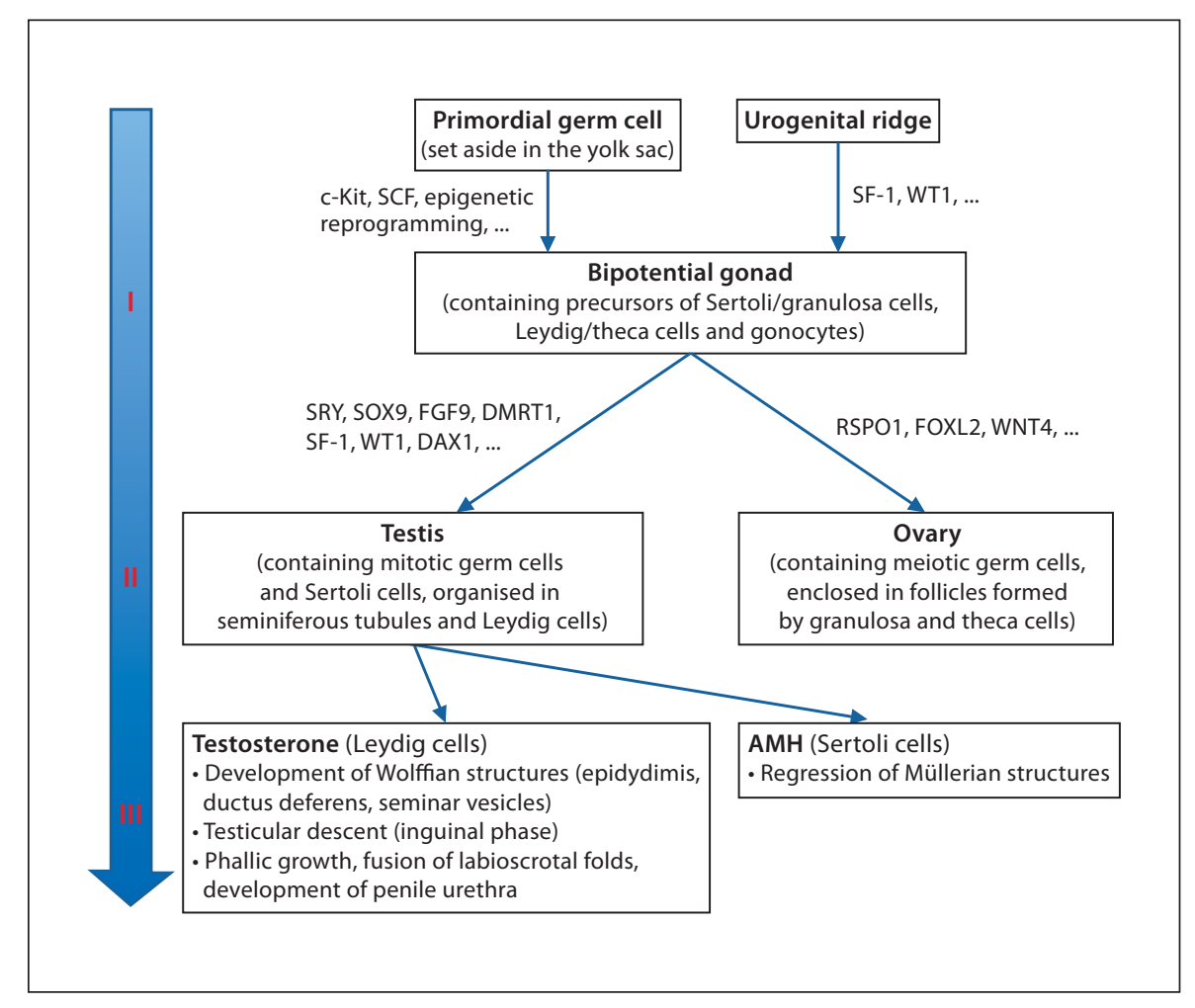

testis-determining factor. Sox9 acts immediately downstream of Sry, and upon its sharp activation by the coordinated action of Sry and Sf1, it induces Sertoli cell differentiation of the supportive cell lineage in the bipotential gonad [Bullejos and Koopman, 2005; Sekido and Lovell-Badge, 2008, 2009; Sekido, 2010]. Sry-independent upregulation of Sox9 by prostaglandin, Fgf9 (fibroblast growth factor 9), and autoregulatory loop systems, originating in the differentiating Sertoli cells, firmly establish the final fate of the gonad; meanwhile, the female pathway is fully suppressed [Schlessinger et al., 2010]. Further testis development includes differentiation of Leydig cells and peritubular myoid cells and the specific organization of these different cell types: testis tubules containing Sertoli cells and germ cells (GCs) and Leydig cells residing in small groups in between these tubules. At this stage, other genes are implicated, such as Amh (anti-Mullerian hormone), Daxl (nuclear receptor subfamily 0, group B, member 1, Nr0b1), Dhh (desert hedgehog), and Dmrt1 (doublesex and mab-3 related transcription factor 1) [Wilhelm and Koopman, 2006; Wilhelm et al., 2007a]; an additional role for Dmrt1 in earlier stages of sex determination has been suggested [Nakamura et al., 2008]. Hormone production starts early in the developing testis.
Leydig cells produce insulin like factor 3 (Insl-3), involved in the transabdominal phase of testicular descent [Virtanen et al., 2007], and testosterone, important for virilization of the external genitalia, via peripheral conversion to dihydrotestosterone. Both testosterone and dihydrotestosterone act through binding on the androgen receptor. Sertoli cells produce large amounts of AMH, essential for regression of the Müllerian ducts [Kobayashi and Behringer, 2003].

In the XX gonad, upregulation of Rspol and Foxl2 (forkhead box L2) is detected from $11.5 \mathrm{dpc}$ onwards; however, the first morphological changes (entry of germ cells into meiosis) are only seen at $13.5 \mathrm{dpc}$ [Ottolenghi et al., 2005; Parma et al., 2006]. It is believed that both Rspo1 (acting through the $\beta$-catenin/Wnt4 (wingless-related MMTV integration site 4) pathway) and Foxl2 are indispensable for proper ovarian development. Although they serve 2 complementary and independent pathways, they cooperate in suppressing any male signals (mainly Sox9) [Nef and Vassalli, 2009; Schlessinger et al., 2010]. The role of Foxl2 in follicular development has been well characterized [De Baere et al., 2009]. Recently, it was shown that loss of Foxl2 function throughout life causes somatic reprogramming of the ovary, resulting in the gain of tes- 
Table 1. Classification of DSDs (modified from Hughes et al. [2006])

\begin{tabular}{|c|c|c|}
\hline Sex chromosomal DSD & 46,XY DSD & 46,XX DSD \\
\hline $\begin{array}{l}\text { 45,X (Turner syndrome and variants) } \\
\text { 47,XXY (Klinefelter syndrome } \\
\quad \text { and variants) } \\
45, \mathrm{X} / 46, \mathrm{XY} \text { and variants } \\
46, \mathrm{XX} / 46, \mathrm{XY} \text { and variants }\end{array}$ & $\begin{array}{l}\text { Testicular GD } \\
\text { complete GD } \\
\text { partial GD } \\
\text { gonadal regression } \\
\text { ovotesticular DSD } \\
\text { Disorder of androgen biosynthesis or action } \\
\text { disorder of androgen biosynthesis } \\
\text { defective androgen action } \\
\text { LH receptor defect } \\
\text { Defective action of AMH or AMH receptor } \\
\text { Other (cloacal exstrophy, severe } \\
\text { hypospadias, ...) }\end{array}$ & $\begin{array}{l}\text { Ovarian GD } \\
\text { ovotesticular DSD } \\
\text { testicular DSD } \\
\text { Androgen excess } \\
\text { fetal level (e.g. CAH) } \\
\text { feto-placental level (e.g. aromatase } \\
\text { deficiency) } \\
\text { maternal level (e.g. maternal ovarian or } \\
\text { adrenal tumor) } \\
\text { Other (cloacal exstrophy, vaginal atresia, } \\
\text { severe epispadias, ...), Mayer-Rokitansky }\end{array}$ \\
\hline
\end{tabular}

AMH = Anti-Müllerian hormone; CAH = congenital adrenal hyperplasia $;$ DSD = disorder of sex development; GD = gonadal dysgenesis.

ticular characteristics. This important finding stresses the lifelong need for intact Foxl2 signaling to suppress the male pathway [Uhlenhaut et al., 2009]. Ovarian hormone production only starts around puberty.

GCs originate in the yolk sac and migrate through the hindgut to the developing urogenital ridge under the control of the stem cell factor (SCF)-c-KIT signaling system (see below) [Molyneaux and Wylie, 2004]. GC development is sex-specific. However, the process depends on the gonadal context (Sertoli versus granulosa cell differentiation) rather than on the GC karyotype. It is hypothesized that retinoic acid, omnipresent in the developing embryo, induces meiosis of germ cells. Specifically in the male gonad, retinoic acid is degraded by Cyp26b, expressed from Sertoli cells. Recently, Sertoli cell-derived Fgf9 has been presented as a complementary mechanism to commit GCs to the male pathway [Kocer et al., 2009; Bowles and Koopman, 2010]. In the ovary, GCs enter the prophase of meiosis I and then become quiescent. Male GC development is first characterized by mitotic proliferation followed by a resting phase of the spermatogonia during childhood. Meiosis starts around puberty, when spermatogonia differentiate into spermatocytes [Kocer et al., 2009].

Our knowledge on normal human gonadal development and sexual differentiation is only fragmentary and results mainly from casuistically described human phenotypes following from specific genetic alterations, interpreted in the light of the above mentioned animal and in vitro studies [Biason-Lauber et al., 2004; Canto et al.,
2004; Domenice et al., 2004; Parma et al., 2006; Barbaro et al., 2008; Tomaselli et al., 2008; Biason-Lauber and Schoenle, 2009; Hersmus et al., 2009; Lourenco et al., 2009; Meduri et al., 2010; Tannour-Louet et al., 2010]. However, gene expression studies on human fetal gonadal material are now emerging and confirm to a certain extent previously suggested parallelisms between the mouse and human process of gonadal development [Duffin et al., 2009; Houmard et al., 2009].

\section{Disorders of Sex Development}

As a result of the Chicago consensus meeting on the diagnosis and management of DSDs in 2006, the classification system for DSDs has been thoroughly revised [Hughes et al., 2006] (table 1). Essentially, patients are classified into 3 groups according to their karyotype: 46,XX DSD, 46,XY DSD, and sex chromosome aneuploidy- or mosaicism/chimerism-induced gonadal dysgenesis.

46,XX DSD comprises 3 different entities: The most frequently, 46,XX DSD, is caused by extra-gonadal (mostly adrenal, e.g. in the case of congenital adrenal hyperplasia) overproduction of androgens, leading to external virilization with normal internal (ovaries, Müllerian derivatives) sexual development. Less frequently, a 46,XX karyotype is accompanied by gonadal dysgenesis or testicular development, as is the case in testicular or ovotesticular DSD. In no more than $20 \%$ of cases, testicular de- 
Fig. 2. Overview of the androgen biosynthesis and action pathway. Interruption of this pathway leads to undervirilization of 46,XY patients with normal testicular development. Reproduced with permission from Cools et al. [2009].

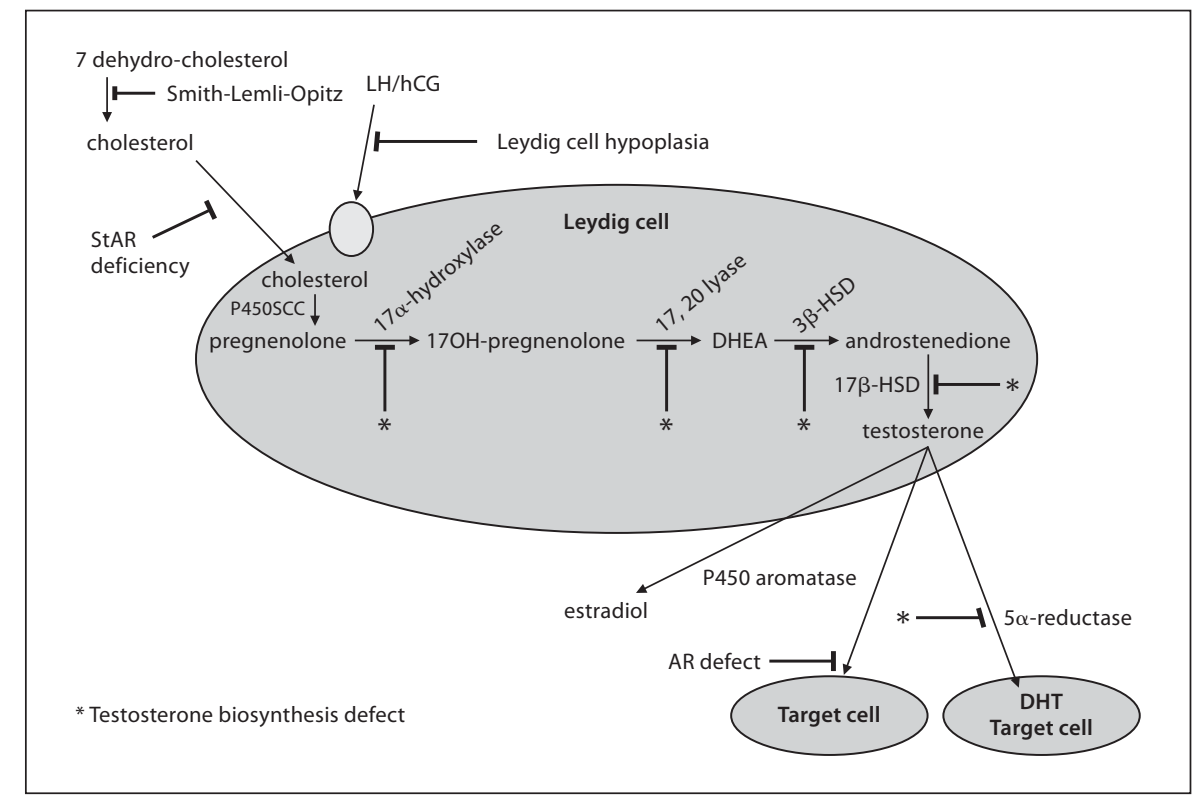

velopment in 46 ,XX patients can be attributed to a translocation of SRY [Fleming and Vilain, 2005]. Other causes remain largely unknown, although most recently, other genes (RSPO1, FOXL2) have been implicated in ovarian development [Ottolenghi et al., 2005; Parma et al., 2006; Ottolenghi et al., 2007]. Normal ovarian development and function but absence of Müllerian duct formation is found in the Mayer-Rokitansky syndrome, which is another relatively frequent cause of 46,XX DSD.

$46, X Y$ DSD represents a very heterogeneous group of patients. Numerous genes, mostly transcription factors, have actually been implicated in the stabilization and development of the urogenital ridge and subsequent testicular development, as reviewed elsewhere [Kim et al., 2006; Ottolenghi et al., 2007; Cools et al., 2009; Piprek, 2009; Wilhelm et al., 2009; Biason-Lauber, 2010; Schlessinger et al., 2010]. Not only mutations or copy number variations in one of these genes, but also timing defects and insufficient levels to reach threshold values may lead to variable degrees of (testicular) gonadal dysgenesis, and hence insufficient hormone production to allow full male internal (Wolffian duct development, regression of Müllerian duct derivatives) and external (testicular descent, fusion of labioscrotal folds, phallic growth, development of the penile urethra) differentiation. In contrast to this first group, testes have normally developed in patients with undervirilization. However, due to disturbed hormone production or action, virilization of male external genitalia is absent or incomplete (fig. 2). Leydig cell hypopla- sia is caused by inactivating mutations of the $\mathrm{LH} / \mathrm{hCG}$ receptor. Disorders of androgen synthesis comprise enzyme defects involved in all consecutive steps of sex steroidogenesis. Androgen action can be fully (complete androgen insensitivity syndrome) or partially (partial androgen insensitivity syndrome) disrupted due to mutations of the androgen receptor, resulting in variable degrees of undervirilization. Infertility can be the only consequence of reduced androgen action, an entity referred to as minimal androgen insensitivity syndrome. An overview of all published mutations of the androgen receptor is found at http://androgendb.mcgill.ca.

45 , X monosomy (Turner syndrome) leads to normal ovarian development in early fetal life, with rapid loss of germ cells from the 22 nd week of gestation onwards, resulting in a streak gonad around birth or soon thereafter [Modi etal., 2003]. Also in Klinefelter syndrome (47,XXY), initial gonadal development is apparently normal; however, seminiferous tubules display a Sertoli cell only pattern after puberty [Aksglaede et al., 2006]. In both situations, increased apoptosis of germ cells has been attributed to a defective micro-environment and impaired meiosis of aneuploid germ cells [Kocer et al., 2009].

Obvious opposing signals cause gonadal dysgenesis in patients with 45,X/46,XY mosaicism and 46,XX/46,XY chimerism. However, the resulting gonadal differentiation patterns are strikingly different in both situations (manuscript in preparation) and will be discussed in more detail below. 
This new classification system has gained acceptance over the following years, and although still under debate - which is actually the goal of this living document - it is presently used on a widespread scale [Pasterski et al., 2010]. Emerging problems are amongst others the necessity of a gonadal biopsy or gonadectomy to classify patients correctly, which is not routinely performed in every patient, especially at the time of diagnostic workup. Partial gonadal dysgenesis, such as in heterozygous NR5A1 (the gene encoding steroidogenic factor 1, SF1) mutations, is sometimes more apparent on a functional than on a pathological level [Coutant et al., 2007; Ferrazde-Souza et al., 2010; Kohler and Achermann, 2010] (and personal observations). Gene regulation disorders or epigenetic modifications, such as expected in undervirilization associated with severe intrauterine growth retardation, are not included in the classification system in its present form. Most importantly, the actual classification system does not allow answering the question who should be investigated. In other words: what is the cut-off (e.g. based on the Prader or external masculinization score) [Ahmed et al., 2000; Ahmed and Rodie, 2010] to distinguish DSD from the more benign forms of the 'testicular dysgenesis syndrome', as proposed by Skakkebaek [2004] and Skakkebaek et al. [2007]? This model, mainly based on epidemiological observations, links various manifestations of decreased testicular function, such as cryptorchidism, hypospadias, sub(in)fertility, and/or an increased risk for development of a type II germ cell tumor (GCT), to a disturbed process of intrauterine gonadogenesis as a common etiological factor in genetically predisposed individuals.

Finally, patient advocacy groups question the use of the word 'disorder' to describe their condition and stress the fact that the karyotype, although of main importance in the classification system, is often felt as irrelevant and not helpful for their understanding or acceptance of their condition [Aaronson and Aaronson, 2010; Davies et al., 2010; Liao et al., 2010].

\section{Type II Germ Cell Tumors}

Traditionally, GCTs are classified according to their histological appearance. A new classification system additionally taking into account (patho)biological and genetic characteristics has been developed [Oosterhuis and Looijenga, 2005] and accepted by the WHO (table 2). Only the type II GCTs from this classification system occur with increased incidence in DSD patients and are

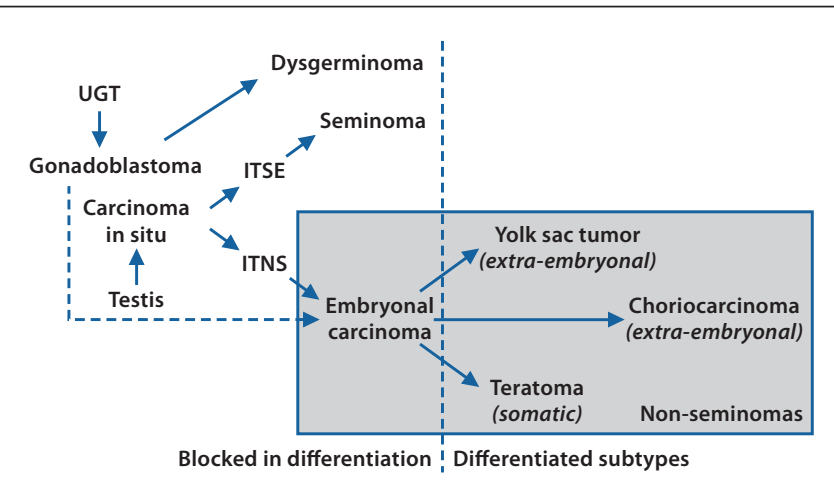

Fig. 3. Overview of the different histological presentations of type II GCTs. Modified from van de Geijn et al. [2009]. Arrows indicate possible progression from one precursor or neoplastic lesion into another. The dashed arrow represents a less frequent progression. UGT $=$ Undifferentiated gonadal tissue; ITSE = intratesticular seminoma; ITNS = intratesticular non-seminoma.

thus of specific interest for this review. The common cell of origin of all type II GCTs is the primordial germ cell (PGC), called gonocyte upon arrival in the developing urogenital ridge. Following neoplastic transformation and proliferation of this PGC/gonocyte, an in situ neoplastic lesion is formed. Depending on the biological and histological context of the surrounding cells (see below), this lesion is described as carcinoma in situ (CIS) (Sertoli cell context) or gonadoblastoma (GB) (granulosa cell context) at a pre-invasive stage, developing into either seminoma/dysgerminoma or non-seminoma upon invasiveness [Oosterhuis and Looijenga, 2005; Hersmus et al., 2009]. Seminoma/dysgerminoma is the invasive malignant counterpart of the PGC/gonocyte. Non-seminomas can be composed of various histological elements, reflecting the pluripotent state of the PGC/gonocyte: embryonal carcinoma is the undifferentiated stem cell component, somatic differentiation leads to teratoma, extraembryonic differentiation gives rise to yolk sac tumors and choriocarcinoma (fig. 3) [van de Geijn et al., 2009]. The histological and expression profile of seminoma and dysgerminoma being very similar, it has been suggested that these tumors are in fact the same [Gillis et al., 2007; Hersmus et al., 2008a]. However, according to the histological context in which they occur, they are recognized by the pathologist on routine examination as seminoma of the testis or dysgerminoma of the ovary and dysgenetic gonad [Hersmus et al., 2008b, 2009]. Moreover, in the ovary and dysgenetic (essentially abdominal) gonad, dysgerminoma, rather than non-seminoma, is encoun- 
Table 2. Classification system for human germ cell tumors based on age at presentation, localization, histological appearance, cell of origin, and biological characteristics (modified from Oosterhuis and Looijenga [2005])

\begin{tabular}{|c|c|c|c|c|c|c|}
\hline Type & Anatomical site & Phenotype & Age & Originating cell & $\begin{array}{l}\text { Genomic } \\
\text { imprinting }\end{array}$ & Genotype \\
\hline I & $\begin{array}{l}\text { testis, ovary, sacral } \\
\text { region, retroperito- } \\
\text { neum, mediastinum, } \\
\text { neck, midline brain, } \\
\text { other rare sites }\end{array}$ & $\begin{array}{l}\text { (immature) teratoma/ } \\
\text { yolk sac tumor }\end{array}$ & $\begin{array}{l}\text { neonates and } \\
\text { children }\end{array}$ & $\begin{array}{l}\text { early PGC/ } \\
\text { gonocyte }\end{array}$ & $\begin{array}{l}\text { biparental } \\
\text { partially erased }\end{array}$ & $\begin{array}{l}\text { diploid (teratoma), aneuploid } \\
\text { (yolk sac tumor): gain of } 1 \mathrm{q} \text {, } \\
12(\mathrm{p} 13 \text { ) and } 20 \mathrm{q} \text {, loss of } 1 \mathrm{p}, 4 \\
\text { and } 6 \mathrm{q}\end{array}$ \\
\hline \multirow{2}{*}{$\mathrm{II}^{\mathrm{a}}$} & ovary & $\begin{array}{l}\text { dysgerminoma/ } \\
\text { non-seminoma }\end{array}$ & $>4 \mathrm{y}$ & PGC/gonocyte & erased & aneuploid \\
\hline & dysgenetic gonad & $\begin{array}{l}\text { dysgerminoma/ } \\
\text { non-seminoma }\end{array}$ & congenital & PGC/gonocyte & erased & diploid/tetraploid \\
\hline IV & ovary & dermoid cyst & children/adults & $\begin{array}{l}\text { oogonia/ } \\
\text { oocyte }\end{array}$ & $\begin{array}{l}\text { partially com- } \\
\text { plete maternal }\end{array}$ & $\begin{array}{l}\text { (near) diploid, diploid/ } \\
\text { tetraploid, peritriploid } \\
\text { (gain of X, 7, 12, and } 15 \text { ) }\end{array}$ \\
\hline $\mathrm{V}$ & placenta/uterus & hydatidiform mole & fertile period & $\begin{array}{l}\text { empty ovum/ } \\
\text { spermatozoa }\end{array}$ & $\begin{array}{l}\text { completely } \\
\text { paternal }\end{array}$ & diploid (XX and XY) \\
\hline
\end{tabular}

$y=$ Years; PGC = primordial germ cell. ${ }^{\text {a }}$ Germ cell tumors occurring along the midline of the body (anterior mediastinum, midline of the brain) also belong to the group of type II germ cell tumors.

tered. In this context it is of relevance that in the abdominal (cryptorchid) testis, seminoma is also more frequently found than the various forms of non-seminoma [Ogunbiyi et al., 1996].

\section{The Testis-Specific Protein on the Y Chromosome}

For a long time it has been known that the presence of the Y chromosome in DSD patients - eventually only at the gonadal level - is associated with an increased risk for the development of GCTs [Scully, 1970; Verp and Simpson, 1987]. Thus, these tumors are mainly encountered in $46, \mathrm{XY}$ DSD and 45,X/46,XY DSD and theoretically also in patients with $46, \mathrm{XX} / 46, \mathrm{XY}$ DSD and 46 , XX DSD cases with translocation of a specific part of the Y chromosome. However, tumor risk in these different groups of patients is highly heterogeneous and can be - at least in part - estimated based on a specific set of parameters. These include more general factors related to the testicu- lar dysgenesis syndrome [Skakkebaek, 2004; Skakkebaek et al., 2007] such as cryptorchism and decreased testosterone production as well as parameters specific for DSDs such as the level of gonadal differentiation, the capacity of immature and sometimes co-present Sertoli and granulosa cells to control germ cell behavior, and the potential of the germ cells to survive in the unsupportive microenvironment (see below). These parameters are related to a certain extent to the underlying genetic cause and the phenotype of the individual patient.

The GB region proximally on Yp (GBY) has been identified as the smallest $Y$ chromosomal region that patients with gonadal dysgenesis and GBs have in common [Page, 1987]. The TSPY (testis-specific protein on the Y chromosome) gene within GBY has been identified as the most likely candidate gene involved in malignant proliferation [Lau et al., 2000; Kersemaekers et al., 2005]. TSPY contains a SET/NAP domain that is present in a family of cyclin $\mathrm{B}$ and/or histone-binding proteins represented by the oncoprotein SET and the nucleosome assembly pro- 
tein 1 (NAP1), which is involved in cell cycle regulation and replication. The specific role of TSPY is not fully understood, but its function has been related to cell-cycle control and promotion of proliferation in a phosphorylation-dependent manner; specifically, it has been shown to mediate a rapid transition of cells to the G2/M phase [Oram et al., 2006]. TSPY is normally expressed in spermatogonia and primary spermatocytes [Honecker et al., 2004]. Immunohistochemical TSPY staining is invariably remarkably intense in pre-meiotic germ cells in DSD and otherwise maldeveloped gonads, and TSPY has been shown to be upregulated in GB and CIS in DSD patients as well as in normal males with pre-invasive germ cell tumors [Lau et al., 2000; Cools et al., 2005, 2006a, b; Li et al., 2007a]. Expression of TSPY decreases upon invasiveness of these tumors [Kersemaekers et al., 2005]. Germ cell numbers are in general severely reduced in a suboptimal environment (e.g. cryptorchidism, testosterone deficiency). Taken together, these data suggest that in these conditions, a subset of germ cells are able to escape apoptosis by increasing survival (by upregulation or retention of OCT3/4, see below) and proliferation (by upregulation of TSPY) mechanisms [Cools et al., 2006c].

\section{POU5F1 - Octamer-Binding Protein 3/4}

POU5F1 (POU domain, class 5, transcription factorl) encodes the octamer-binding transcription factor $3 / 4$ (OCT3/4). POU5F1 expression is observed in undifferentiated cell types, such as embryonic stem (ES) cells and is a key regulator in the maintenance of pluripotency of these cells [Niwa et al. 2000; Matin et al., 2004]. Increased or decreased levels of OCT3/4 induce differentiation of the ES cells to respectively endo- and mesoderm or ectoderm [Niwa et al., 2000]. Maintenance of critical OCT3/4 levels in ES cells confine a subset of these cells to the germ cell lineage [Okamura et al., 2008]. Interestingly, downregulation of OCT3/4 in PGCs induces apoptosis rather than differentiation [Kehler et al., 2004], suggesting a role of OCT3/4 in promoting survival of PGCs. In female GCs, disappearance of OCT3/4 expression coincides with entry into meiosis [Pesce et al., 1998; Rajpert-De Meyts et al., 2004; Stoop et al., 2005]. In male GCs, luminal gonocytes normally express OCT3/4. Upon gonadal maturation, GCs migrate towards the basal membrane of the tubules and differentiate into pre-spermatogonia. This process is associated with loss of OCT3/4 expression [Honecker et al., 2004]. At birth, only scarce luminal OCT3/4-positive cells persist in control gonads, and at the age of 3 months, no OCT3/4 positivity can be detected any more [Cools et al., 2006a].

OCT3/4 has been shown to be consistently expressed in all germ cell tumors with pluripotent potential (i.e., seminoma, dysgerminoma, germinoma of the brain and midline, and embryonal carcinoma) as well as in their precursor lesions CIS and GB [Looijenga et al., 2003a]. Over the years, it turned out to be the most reliable immunohistochemical marker to diagnose these tumors [de Jong et al., 2005]. However, germ cells delayed in their maturation are characterized by prolonged luminal expression of OCT3/4 and represent an important pitfall. Therefore, additional criteria have been developed to correctly differentiate maturation delay from CIS in testicular biopsies and prophylactic gonadectomy material of young children [Cools et al., 2005]. Developmental delay of germ cells has first been described in DSD gonads [Rajpert-De Meyts et al., 1996, 2004]. However, later it has been recognized as a common pathogenetic mechanism in the various presentations of the testicular dysgenesis syndrome, resulting from insufficient nutritional support from the Sertoli cells [Rajpert-De Meyts et al., 1998; Hoei-Hansen et al., 2003; Cools et al., 2006a]. Prolonged expression of the survival factor OCT3/4 in germ cells finally reaching the basal membrane, accompanied by increased mitotic pressure (TSPY, see above), has been proposed to be of relevance in the pathogenesis of GCTs in DSD patients [Kersemaekers et al., 2005; Cools et al., 2006c; Looijenga et al., 2007; Hersmus et al., 2008a; van de Geijn et al., 2009; Looijenga et al., 2010].

\section{The Stem Cell Factor-c-KIT System}

c-KIT is expressed by immature germ cells and is downregulated in human spermatogonia [Honecker et al., 2004]. Its ligand SCF (stem cell factor, also known as KITLG (kit ligand)) is expressed by Sertoli cells. During embryogenesis, the SCF-c-KIT signaling system is essential for the survival and correct migration of PGCs from the yolk sac to the urogenital ridge [Loveland and Schlatt, 1997]. In adult testes, Sertoli cells secrete a soluble form, stimulating testosterone production by Leydig cells, and a membrane-bound form, supporting the germ cells. CIS and GB display aberrant c-KIT expression which is mostly lost upon invasiveness [Rajpert-De Meyts and Skakkebaek, 1994; Biermann and Steger, 2007]. Activating mutations (mostly codon 816 mutations) of $c$-KIT play an important role in GC oncogenesis [Looijenga et al., 2003b; van de Geijn et al., 2009]. Evidence for a pathogenetic role 
of the SCF-c-KIT mechanism in testicular GCT development is accumulating, especially since genome-wide association studies have identified common variations in SCF alleles as very likely susceptibility loci for GCT risk [Kanetsky et al., 2009; Rapley et al., 2009].

Recently it was shown that SCF is consistently detected in CIS, GB, and testicular GCT-derived cell lines, but not in prepubertal control testes, not even in those displaying maturation delays as appreciated by OCT3/4 staining experiments (see above). Immunohistochemical staining for SCF may thus constitute an important additional marker supporting the differential diagnosis between maturation delay and neoplastic transformation of germ cells [Stoop et al., 2008; van de Geijn et al., 2009].

\section{SOX9 and FOXL2 as Indicators of Male and Female Gonadal Determination}

In 1991 it was demonstrated that Sry, after having been introduced in chromosomally female mice embryos, induces testis formation, thus leading to the concept of Sry as the testis-determining gene [Koopman et al., 1991]. Over a decade later, the same group identified Sox9, immediately downstream of Sry, rather than Sry itself, as pivotal in Sertoli cell differentiation, testis cord formation, and as the activator of a complex genetic cascade orchestrating full testicular development. Sry, enhanced by Sf1, is essential in upregulating Sox 9 in the bipotential gonad, but the signal rapidly extinguishes. Sox9, upon activation by Sry, is expressed in pre-Sertoli cells and induces rapid differentiation of these cells. Sertoli cells induce Fgf9 and prostaglandin D2, involved in the recruitment and ongoing differentiation of neighboring preSertoli cells. At this stage, testis determination becomes Sry-independent. In contrast to Sry, gonadal Sox9 expression is maintained throughout life and indicates Sertoli cell differentiation. Sertoli cells are essential in sex cord and tubule formation and thus constitute the basis of the characteristic testicular architecture [Wilhelm et al., 2007a, b; Piprek, 2009; Sekido and Lovell-Badge, 2009]. Both timing defects and abnormal spatial distribution of Sry, although subtle, may lead to defective or decreased Sox9 activation, resulting in insufficient recruitment mechanisms. In genetically manipulated mice it was shown that supportive cells in the bipotential gonad that are not reached in time by the Sry signal do not differentiate into Sox9-expressing Sertoli cells. In contrast, after a short latency period, they differentiate as Foxl2 expressing granulosa cells, resulting in local ovarian differentia- tion and follicle development, and leading to ovotestes formation. Of note, in these experiments, testis differentiation was typically seen in the center of the gonad, where the Sry signal starts, whereas the poles, which are reached latest by Sry in normal circumstances, are prone to ovarian differentiation upon delayed Sry signaling. Expression of Sox 9 and Foxl2 was found to be mutually exclusive in the individual cells [Wilhelm et al., 2009].

Immunohistochemical staining experiments in dysgenetic gonads of DSD patients have shown similar mechanisms (fig. 4) [Hersmus et al., 2008b]. In the normal testis, Sertoli cells intensely express SOX9, whereas the intertubular milieu does not contain any SOX9-positive cells. FOXL2 expression is never encountered in the normal human testis. In contrast, maturing follicles are characterized by FOXL2-positive granulosa cells surrounding the germ cells. The interstitial stroma is free of FOXL2 expression, and SOX9 is absent in ovaries (unpublished observations). The degree of male or female determination of DSD gonads is highly variable and can be placed somewhere on the virtual continuum between the normal testis and the normal ovary as depicted above. Mutations in genes involved in testicular formation (e.g. $S R Y, S O X 9$ ) may lead to insufficient suppression and/ or upregulation of ovarian promoting genes (RSPO1, FOXL2) [Schlessinger et al., 2010]. We and others hypothesize that meiosis of XY germ cells residing in a female (predominantly FOXL2 positive) environment is blocked due to the incongruence between these XY germ cells and their environment, leading to germ cell apoptosis [Kocer et al., 2009]. The inability to form follicles results in loss of ovarian organization and, hence, replacement of these functional cells by streak tissue (containing mostly fibroblasts). Weak FOXL2 expression is sometimes noticed in a 46,XY streak. However, primitive sex cords can often be recognized, even in $46, \mathrm{XY}$ gonads with a proven $S R Y$ mutation or deletion, consisting of SOX9 expressing Sertoli-like cells. Whether this is due to intrinsic SOX9 activity or a process of 'transdifferentiation' into a testis following loss of FOXL2 expression, as was demonstrated in the mouse gonad (see above), is actually unclear (manuscript in preparation).

Also in the dysgenetic testis, Sertoli cells display SOX9 expression. Unlike in the ovary, testicular architecture is preserved in the absence of germ cells, resulting in Sertoli cell only tubules, which is a frequent finding in dysgenetic testes (unpublished observations). Severely dysgenetic testis tubules are characterized by structural abnormalities such as branching tubules, a thin basal lamina, or penetration of the testicular capsule. In contrast to 


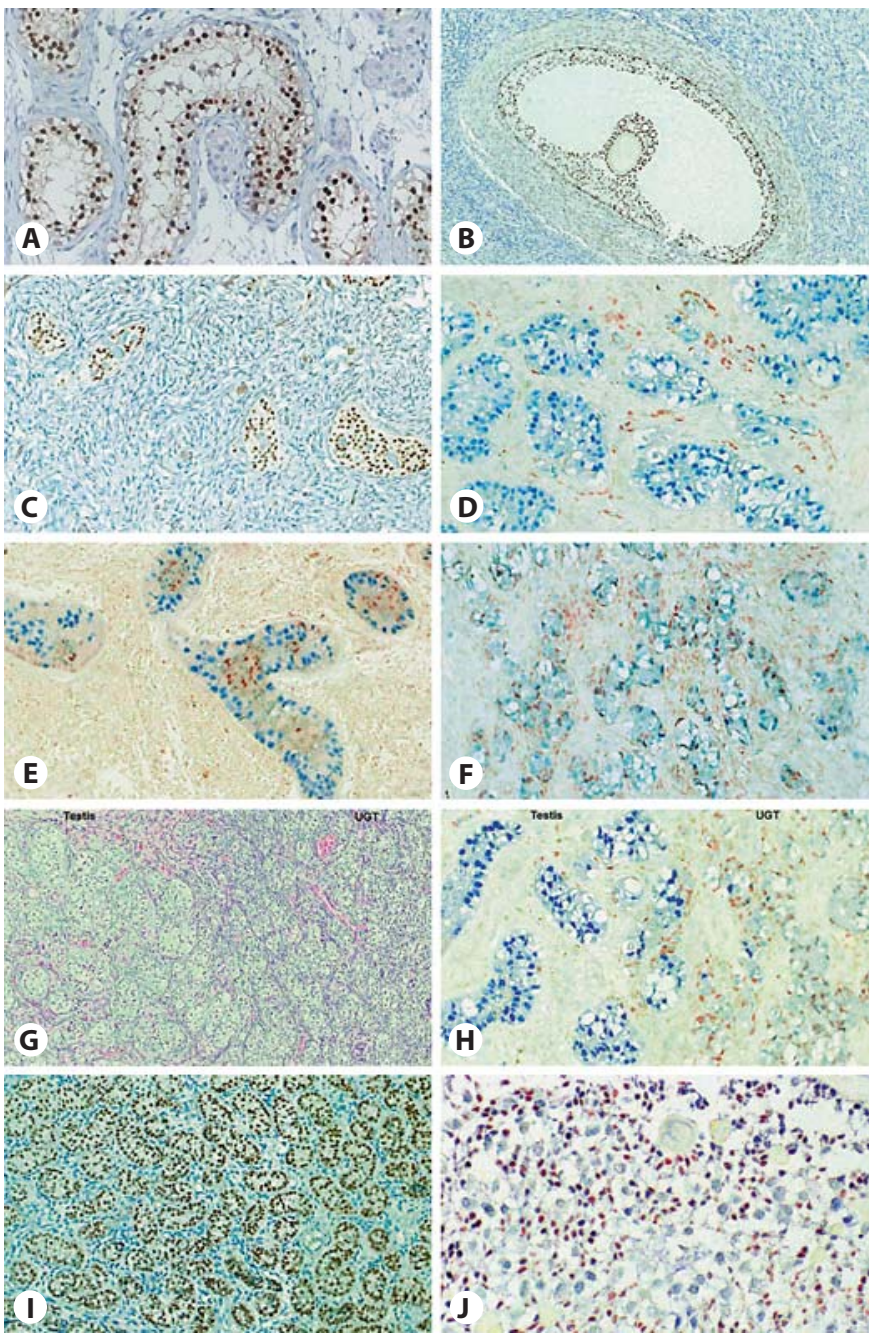

Fig.4. A SOX9 expression in Sertoli cells of the normal testis (46,XY, SOX9 staining, $200 \times$ ). B FOXL2 expression in growing follicle granulosa cells of the normal ovary (46,XX, FOXL2 staining, $100 \times)$. C Streak consisting of fibrous tissue with dispersed primitive tubule-like structures containing SOX9-positive Sertoli cells $(45, \mathrm{X} / 46, \mathrm{XY}$ mosaicism, SOX9 staining, 200×). D Dysgenetic testis with Sertoli cell-specific SOX9 expression within the tubules, and FOXL2-positive granulosa cells in between the tubules (45,X/46,XY mosaicism, SOX9-FOXL2 double staining, 200X). E Dysgenetic testis with SOX9-positive Sertoli cells and FOXL2-positive granulosa cells both organized within the testis tubules. 46,XY gonadal dysgenesis. SOX9 and FOXL2 expression are mutually exclusive (SOX9-FOXL2 double staining, 200 X). F Undifferentiated gonadal tissue with balanced expression of SOX9 and FOXL2 (45,X/46,XY mosaicism, SOX9-FOXL2 double staining, $200 \times$ ). G Transitional region with dysgenetic testis (left) and undifferentiated gonadal tissue (right) $(45, \mathrm{X} / 46, \mathrm{XY}$ mosaicism, HE staining, $200 \times)$. H Same gonad, SOX9-positive Sertoli cells in the testis (left) and co-expression of SOX9 and FOXL2 in undifferentiated gonadal tissue (right) (45,X/46,XY mosaicism, SOX9-FOXL2 double staining, 200X). I SOX9 expression in 46,XX, SRY- testis tissue (SOX9 staining, $200 \times)$. J Co-presence of SOX9 and FOXL2-positive cells in the supportive cell lineage of gonadoblastoma (46,XY gonadal dysgenesis (SRY mutation), SOX9-FOXL2 double staining, $200 \times$ ).

Gonadal Development and Malignant

Tumor Formation in DSD Patients normal testes, FOXL2-positive (granulosa) cells can be present, either next to SOX9-positive Sertoli cells within the tubules or in the intertubular milieu, which sometimes has the aspect of ovarian-type stroma.

Undifferentiated gonadal tissue (UGT) has been described by our group as a gonadal pattern found specifically in patients with gonadal dysgenesis and characterized by 'immature, OCT3/4-expressing germ cells either dispersed in ovarian-type stroma or organized together with Sertoli/granulosa like cells in cord-like structures, reminiscent of primitive sex cords'. Moreover, it was recognized as the precursor lesion for the development of GB [Cools et al., 2006b]. Upon availability of immunohistochemical markers for SOX9 and FOXL2, it was shown indeed that UGT consists of intermingled SOX9- (Sertoli) and FOXL2- (granulosa) expressing supportive cells, with often a predominance of FOXL2. Likewise, the supportive lineage in GB displays either unique FOXL2 expression or a combination of FOXL2 and SOX9 expression (fig. 4J) [Hersmus et al., 2008b, 2009].

\section{Gonadal Determination in Relation to the Underlying Genetic Defect}

DSD is an umbrella term, reflecting a highly heterogeneous group of disorders and resulting, as described above, in a variety of gonadal differentiation patterns that can often be placed somewhere on the continuum between the normal testis and the normal ovary. However, upon examination of over 200 DSD gonads, some general principles become obvious (fig. 5).

If the genetic defect underlying the DSD is involved at the top of the gonadal differentiation cascade (e.g. WT1, $S R Y, 45, \mathrm{X} / 46, \mathrm{XY}$ mosaicism; fig. 1, level I and II), this generally results in severe gonadal dysgenesis, with copresence of SOX9- and FOXL2-positive cells in dysgenetic testis or UGT. Germ cells, most often severely reduced in number, are likely to express OCT $3 / 4$ even years after birth and thus display maturation arrest. Alternatively, a streak or even regression of gonadal tissue can be found [Hersmus et al., 2008a] (and personal observations). Gene mutations causing disturbed hormone production (e.g. AR, HSD17B3, LHR; fig. 1, level III) result in normal testicular differentiation, and the supportive cells reside in normally shaped testis tubules and exclusively express SOX9. Limited maturation delay of germ cells and a decreased germ cell count in relation to patient age are the most frequent abnormalities [Cools et al., 2005, 2006a] (and manuscript in preparation). GCT risk in pa- 


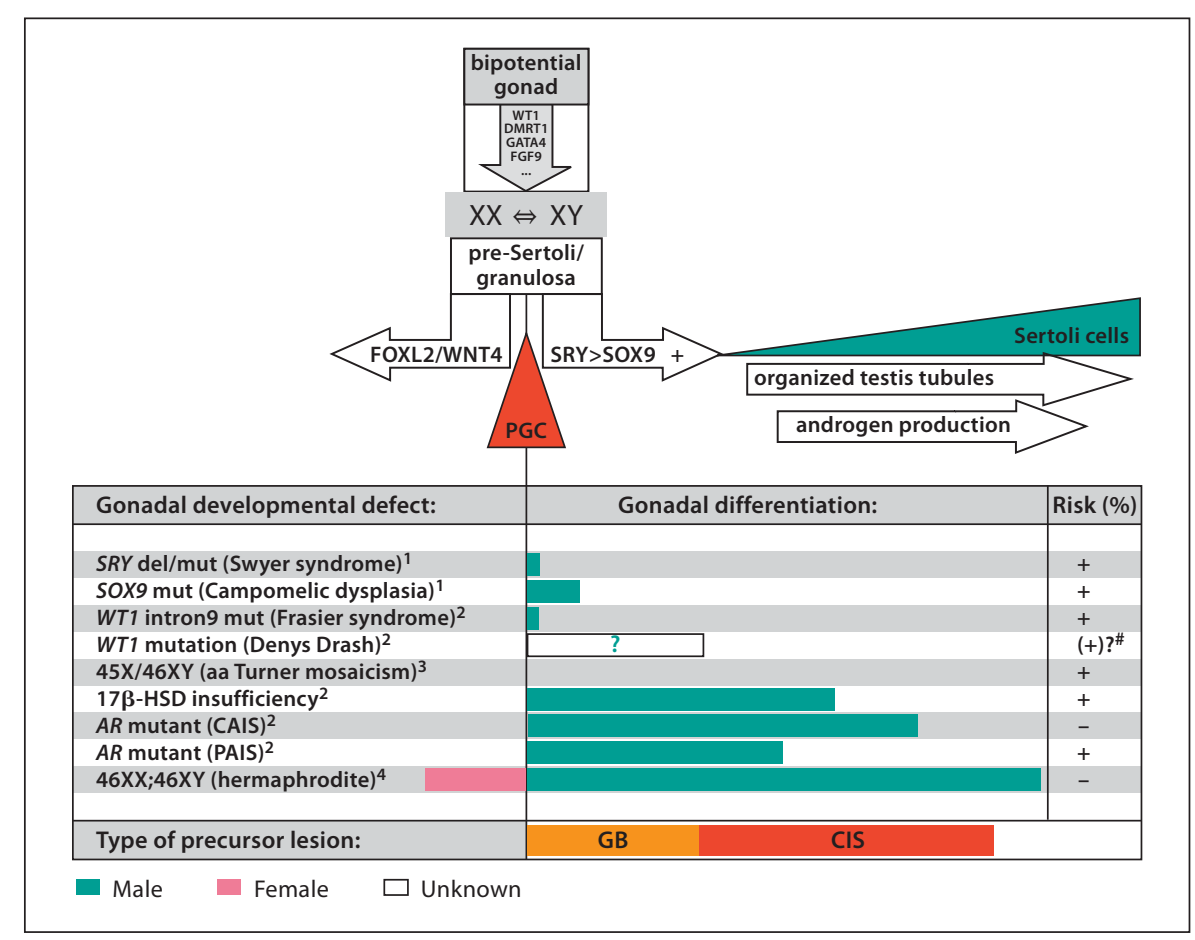

Fig. 5. Schematic representation qualitatively indicating how various known genetic mutations in the gonadal differentiation cascade interfere with this process and hence may lead to increased tumor risk. Reproduced with permission from Hersmus et al. [2008a]. Upper panel: The fate of the primordial germ cell is determined by the environmental sex determination and independent of its own chromosomal constitution. The female pathway is characterized by RSPO1/WNT4/ $\beta$-catenin and FOXL 2 activation and leads to ovarian differentiation and follicle formation. There is no increased risk for germ cell tumor development in this situation. In XY DSD gonads, this normal female pathway is inhibited, irrespective of the underlying cause, except in XX/XY chimerism. Lower panel: Depending on the genetic defect, the testicular differentiation pathway is blocked at an early stage with high tumor risk as a consequence, presumably gonadoblastoma in

tients with NR5A1 mutations remains somewhat enigmatic. Severe (homozygous and heterozygous with dominant negative effect) mutations are extremely rare and result in combined complete gonadal dysgenesis and primary adrenal insufficiency. On theoretical grounds, a malignancy risk similar to SRY or WT1 mutations is expected; however, no tumors were described in the 2 hitherto reported patients [Achermann et al., 2001; Ferrazde-Souza et al., 2010]. Heterozygous NR5A1 mutations or deletions, resulting in partial gonadal dysgenesis and normal adrenal function, are increasingly observed. The clinical phenotype is highly heterogeneous, varying from (almost) normal female (the so-called 'severe phenotype') undifferentiated gonadal tissue or carcinoma in situ in dysgenetic testis tissue. In disorders of androgen synthesis or action, the testicular differentiation process is complete, but maturation of germ cells is delayed, resulting in a lower tumor risk, presumably carcinoma in situ. This overview is not meant to include all known defects, but rather demonstrates on the basis of some examples the principle of how a given genetic defect may influence tumor risk (average risk 0.01\%), depending on its level of action. $-=0.5-$ $5 \%$ risk; $+=>10 \%$ risk. DSD classification: $1=46, \mathrm{XY}$ (complete) gonadal dysgenesis; $2=46$, XY DSD; 3 = sex chromosome DSD; 4 = ovostesticular DSD. ${ }^{*}=$ no Denys Drash WT1 mutant patient found in literature with gonadoblastoma, although this has been reported for non-specific Denys Drash patients. GB = Gonadoblastoma; CIS = carcinoma in situ.

to mild undervirilization (isolated hypospadias, infertility). Interestingly, even in the 'severe phenotype', gonadal dysgenesis is apparent on a functional, rather than on a pathological, level as testes are often described as only mildly dysgenetic [Ferraz-de-Souza et al., 2010; Kohler and Achermann, 2010] (and personal observations). To our knowledge, only one case of (bilateral) CIS has been observed [Cools et al., submitted]. It remains to be established if the clinical, rather than the gonadal, phenotype of patients with NR5A1 mutations relates to tumor risk and/or if other factors than the cryptorchid testicular position alone interfere with malignancy risk in the welldeveloped testes from a subset of these patients. 
To a certain extent, also the karyotype is predictive with regard to the expected gonadal differentiation pattern. 46,XX testicular DSDs with or without translocation of $S R Y$ invariably present with well differentiated testes. However, normally shaped tubules remain immature and display a Sertoli cell only pattern. Leydig cell hyperplasia may or may not be present, and testicular atrophy is expected in older patients. Even in patients without demonstrable SRY and with no evidence for SOX9 duplication or RSPO1 mutation, all Sertoli cells express SOX9, whereas FOXL2 expression is absent (manuscript in preparation), suggesting SRY independent upregulation of SOX9 (fig. 4I) as was suggested in mice [Wilhelm et al., 2007b; Piprek, 2009].

Gonadal differentiation in 46,XX ovotesticular DSD and in $46, \mathrm{XX} / 46, \mathrm{XY}$ chimerism is similar and characterized by the combined presence of normally differentiated ovarian and testicular tissue in one person or even in the same gonad. FOXL2 and SOX9 expression are in accordance with the respective histological appearance.

In $45, \mathrm{X} / 46$, XY mosaicism, SRY expression from the $\mathrm{Y}$ chromosome almost invariably induces an initiation of testis development. However, the level of 'testicularization' of the gonad may be very different per gonad, probably related to SRY signal density and the local strength of autoregulatory reinforcement and opposing suppressive mechanisms. As in $46, \mathrm{XY}$ gonadal dysgenesis, the resulting level of gonadal differentiation can vary from apparently well-developed testis tubules, with, in general, decreased numbers of germ cells displaying maturation delay to UGT with germ cells blocked in their maturation or a streak with often some SOX9 expression in primitive cord-like organizations (fig. 4C). Moreover, it has to be remembered that one gonad can contain areas with various differentiation patterns, e.g. a combination of dysgenetic testis with UGT (fig. $4 \mathrm{G}$ and $\mathrm{H}$ ).

\section{Tumor Risk in Relation to the Gonadal Differentiation Pattern and the Phenotypic Presentation of the Patient}

Tumor development in DSD patients has been associated with the GBY locus [Page, 1987] and with the coexpression of TSPY [Lau, 1999; Lau et al., 2000] and OCT3/4 in (pre)malignant germ cells [Looijenga et al., 2003a; Kersemaekers et al., 2005] (see above). We hypothesized a pathogenetic mechanism in which OCT3/4 and TSPY, respectively, increase survival and proliferation of the neoplastic germ cells [Cools et al., 2006c; Looijenga et

Gonadal Development and Malignant

Tumor Formation in DSD Patients al., 2007; Hersmus et al., 2008a; Looijenga et al., 2010]. TSPY expression is qualitatively increased in germ cells residing in an unsupportive micro-environment [Cools et al., 2006c; Li et al., 2007b; van de Geijn et al., 2009]. Maturation delay, characterized by prolonged OCT3/4 expression, is common in testes from patients with undervirilization syndromes [Cools et al., 2005] (and manuscript in preparation). Moreover, developmental delay of germ cells seems to be a common condition in the various disorders that have been related to the testicular dysgenesis syndrome and/or to an increased risk for GCT development, such as cryptorchidism and trisomy 21 , and has been associated with insufficient support from the Sertoli cell environment [Sharpe et al., 2003; Cools et al., 2006a; Virtanen et al., 2007]. In patients with trisomy 21 and with undervirilization syndromes, it has been demonstrated that the testicular architecture is intact and that the developmental delay of germ cells is only mild to moderate, with loss of OCT $3 / 4$ expression in most samples only a few months after birth [Honecker et al., 2004; Cools et al., 2005, 2006a]. In concordance with this observation, tumor risk in these situations is much lower than in patients with gonadal dysgenesis and is likely to be mainly the result of the cryptorchid position. In the dysgenetic gonad, tumor risk is as high as 30\% [Cools et al., 2006c; Hersmus et al., 2008a]. Germ cells are blocked rather than delayed in their maturation, demonstrated by the presence of pluripotent OCT3/4-positive cells in gonadal samples from patients over 10 years of age. From the structural abnormalities and the concomitant expression of SOX9 and FOXL2 in dysgenetic testes and in UGT it can be derived that differentiation of the supportive cell lineage is severely impaired. Germ cells, invariably displaying intense TSPY staining, are very likely to escape the normal control mechanisms exerted by the environment. Thus, it has been noticed that the degree of 'testicularization', defined as the process of testicular differentiation and maturation in its broadest sense, is inversely related to the risk for tumor development [Looijenga et al., 2010].

In $45, \mathrm{X} / 46, \mathrm{XY}$ patients, the relation between the gonadal differentiation pattern, the patient's tumor risk, and his/her phenotype has been examined in detail [Cools et al., 2011]. 45,X/46, XY mosaicism is characterized by extreme phenotypic heterogeneity. The milder phenotype is represented by the phenotypically normal male with infertility and/or short stature. In the pediatric population, the diagnosis is sometimes made at birth by the presence of genital anomalies in males (severe hypospadias, bilateral cryptorchidism, etc.) or frankly ambiguous genitalia, or during childhood in patients with a female phenotype 
and short stature (Turner syndrome). The phenotype can be assessed qualitatively by the Prader stages or quantitatively by the external masculinization score (EMS) [Ahmed and Rodie, 2010]. From this study it became clear that higher EMS scores correlate with the presence of testes, whereas lower scores are more likely to be associated with UGT. In patients with an unambiguously female phenotype, bilateral streak gonads are found in almost all cases. Therefore, in this last group, tumor risk is very low since by definition, a streak does not contain germ cells. It is concluded that in $45, \mathrm{X} / 46, \mathrm{XY}$ mosaicism presenting as Turner syndrome there is a relative indication for prophylactic gonadectomy, taken into account that tumor risk is considerably lower than previously thought (about $1 \%$ instead of $30 \%$ ), but on the other hand, gonads are nonfunctional. Instead, in patients with an ambiguous phenotype (EMS score 1-7), the threshold to perform (repeated) biopsies or gonadectomy should be very low in nonscrotal gonads, mostly consisting of dysgenetic testes or UGT, since tumor risk is thought to be around 50\% in this group. Patients with mild undervirilization (EMS $>7$ ) present with an intermediate risk (around 15\%), and close follow-up is warranted also in this group, especially in non-scrotal gonads. No information on tumor risk is available for boys in whom the mosaic karyotype is an incidental finding, e.g. during the work-up for short stature, but from the above presented data it can be expected that tumor risk is low [Cools et al., 2011].

\section{Conclusions}

Triggered by recent progress that has been made in our understanding of the process of sex determination, mostly derived from genetically manipulated mouse studies and advanced molecular genetic techniques, our knowledge on gonadal (mal)development in humans has increased considerably in recent years. The mechanisms of expression and function of SOX9 and FOXL2 in male and female human gonadal determination seem to be similar in men and mice. However, the human pattern is more complex, resulting, in contrast to what has been described in mice, in DSD patients in a continuum of differentiation patterns from normal testis to normal ovary, depending on local balances between testis- and ovarypromoting signals. Tumor risk is most pronounced in immature and/or poorly differentiated gonadal tissue and can be - at least in part - predicted from the presence of specific immunohistochemical markers. This increase in knowledge has modified our clinical approach to the DSD patient, resulting in an individualized management with regard to tumor risk. Future research and long-term follow-up of these patients is necessary to demonstrate the safety and benefit of this approach.

\section{References}

Aaronson IA, Aaronson AJ: How should we classify intersex disorders? J Pediatr Urol 6:443446 (2010)

Achermann JC, Meeks JJ, Jameson JL: Phenotypic spectrum of mutations in $D A X-1$ and $S F-1$. Mol Cell Endocrinol 185:17-25 (2001).

Ahmed SF, Rodie M: Investigation and initial management of ambiguous genitalia. Best Pract Res Clin Endocrinol Metab 24:197-218 (2010).

Ahmed SF, Khwaja O, Hughes IA: The role of a clinical score in the assessment of ambiguous genitalia. BJU Int 85:120-124 (2000).

-Aksglaede L, Wikstrom AM, Rajpert-De Meyts E, Dunkel L, Skakkebaek NE, Juul A: Natural history of seminiferous tubule degeneration in Klinefelter syndrome. Hum Reprod Up date 12:39-48 (2006).

- Barbaro M, Cicognani A, Balsamo A, Löfgren A, Baldazzi L, et al: Gene dosage imbalances in patients with 46,XY gonadal DSD detected by an in-house-designed synthetic probe set for multiplex ligation-dependent probe amplification analysis. Clin Genet 73:453-464 (2008).
Biason-Lauber A: Control of sex development. Best Pract Res Clin Endocrinol Metab 24: 163-186 (2010).

-Biason-Lauber A, Schoenle EJ: Apparently normal ovarian differentiation in a prepubertal girl with transcriptionally inactive steroidogenic factor 1 (NR5A1/SF-1) and adrenocortical insufficiency. Am J Hum Genet 67: 1563-1568 (2000).

Biason-Lauber A, Konrad D, Navratil F, Schoenle EJ: A WNT4 mutation associated with Mullerian-duct regression and virilization in a 46, XX woman. $\mathrm{N}$ Engl J Med 351:792798 (2004).

Biermann K, Steger K: Epigenetics in male germ cells. J Androl 28:466-480 (2007).

- Bowles J, Koopman P: Sex determination in mammalian germ cells: extrinsic versus intrinsic factors. Reproduction 139:943-958 (2010).

Bullejos M, Koopman P: Delayed Sry and Sox 9 expression in developing mouse gonads underlies B6-Y(DOM) sex reversal. Dev Biol 278:473-481 (2005).
Canto P, Soderlund D, Reyes E, Mendez JP: Mutations in the desert hedgehog $(D H H)$ gene in patients with $46, \mathrm{XY}$ complete pure gonadal dysgenesis. J Clin Endocrinol Metab 89: 4480-4483 (2004).

Cools M, van Aerde K, Kersemaekers AMF, Boter M, Drop SL, et al: Morphological and immunohistochemical differences between gonadal maturation delay and early germ cell neoplasia in patients with undervirilisation syndromes. J Clin Endocrinol Metab 90: 5295-5303 (2005).

-Cools M, Honecker F, Stoop H, Veltman JD, de Krijger RR, et al: Maturation delay of germ cells in trisomy 21 fetuses results in increased risk for the development of testicular germ cell tumors. Hum Pathol 37:101111 (2006a).

Cools M, Stoop H, Kersemaekers AM, Drop SL, Wolffenbuttel KP, et al: Gonadoblastoma arising in undifferentiated gonadal tissue within dysgenetic gonads. J Clin Endocrinol Metab 91:2404-2413 (2006b). 
-Cools M, Drop SL, Wolffenbuttel KP, Oosterhuis JW, Looijenga LH: Germ cell tumors in the intersex gonad: old paths, new directions, moving frontiers. Endocr Rev 27:468-484 (2006).

Cools M, Looijenga LH, Wolffenbuttel KP, Drop SL: Disorders of sex development: update on the genetic background, terminology and risk for the development of germ cell tumors. World J Pediatr 5:93-102 (2009).

Cools M, Pleskacova J, Stoop H, Hoebeke P, Van Laecke E, et al: Gonadal pathology and tumor risk in relation to clinical characteristics in patients with $45, \mathrm{X} / 46, \mathrm{XY}$ mosaicism. J Clin Endocrinol Metab (2011) [E-pub ahead of print].

Coutant R, Mallet D, Lahlou N, Bouhours-Nouet $\mathrm{N}$, Guichet A, et al: Heterozygous mutation of steroidogenic factor-1 in 46,XY subjects may mimic partial androgen insensitivity syndrome. J Clin Endocrinol Metab 92: 2868-2873 (2007).

Davies JH, Knight EJ, Savage A, Brown J, Malone PS: Evaluation of terminology used to describe disorders of sex development. J Pediatr Urol (2010) [Epub ahead of print].

-De Baere E, Fellous M, Veitia RA: The transcription factor FOXL2 in ovarian function and dysfunction. Folia Histochem Cytobiol 47:S43-49 (2009).

de Jong J, Stoop H, Dohle GR, Bangma CH, Kliffen M, et al: Diagnostic value of OCT3/4 for pre-invasive and invasive testicular germ cell tumours. J Pathol 206:242-249 (2005).

- Domenice S, Correa RV, Costa EM, Nishi MY, Vilain E, et al: Mutations in the SRY, DAX1, SF1 and WNT4 genes in Brazilian sex-reversed patients. Braz J Med Biol Res 37:145150 (2004).

-Duffin K, Bayne RA, Childs AJ, Collins C, Anderson RA: The forkhead transcription factor FOXL2 is expressed in somatic cells of the human ovary prior to follicle formation. Mol Hum Reprod 15:771-777 (2009).

Ferraz-de-Souza B, Lin L, Achermann JC: Steroidogenic factor-1 (SF-1, NR5A1) and human disease. Mol Cell Endocrinol 336:198205 (2010).

-Fleming A, Vilain E: The endless quest for sex determination genes. Clin Genet 67:15-25 (2005).

-Gillis AJ, Stoop HJ, Hersmus R, Oosterhuis JW, Sun Y, et al: High-throughput microRNAome analysis in human germ cell tumours. J Pathol 213:319-328 (2007).

Grumbach MM, Hughes IA, Conte FA: Disorders of sex differentiation, in Larsen PR, Kronenberg HM, Melmed S, Polonsky KM (eds): Williams Textbook of Endocrinology, 10th ed, pp 842-1002 (W.B. Saunders, Philadelphia 2003).

- Hersmus R, de Leeuw BH, Wolffenbuttel KP, Drop SL, Oosterhuis JW, et al: New insights into type II germ cell tumor pathogenesis based on studies of patients with various forms of disorders of sex development (DSD). Mol Cell Endocrinol 291:1-10 (2008a).
Hersmus R, Kalfa N, de Leeuw B, Stoop H, Oosterhuis JW, et al: FOXL2 and SOX9 as parameters of female and male gonadal differentiation in patients with various forms of disorders of sex development (DSD). J Pathol 215:31-38 (2008b).

Hersmus R, de Leeuw BH, Stoop H, Bernard P, van Doorn HC, et al: A novel SRY missense mutation affecting nuclear import in a 46,XY female patient with bilateral gonadoblastoma. Eur J Hum Genet 17:1642-1649 (2009).

Hoei-Hansen CE, Holm M, Rajpert-De Meyts E, Skakkebaek NE: Histological evidence of testicular dysgenesis in contralateral biopsies from 218 patients with testicular germ cell cancer. J Pathol 200:370-374 (2003).

Honecker F, Stoop H, de Krijger RR, Chris Lau YF, Bokemeyer C, Looijenga LH: Pathobiological implications of the expression of markers of testicular carcinoma in situ by fetal germ cells. J Pathol 203:849-857 (2004).

Houmard B, Small C, Yang L, Naluai-Cecchini $\mathrm{T}$, Cheng E, et al: Global gene expression in the human fetal testis and ovary. Biol Reprod 81:438-443 (2009).

-Hughes I, Houk C, Ahmed SF, Lee PA: Consensus statement on the management of intersex disorders. Arch Dis Child 91:554-563 (2006).

Kanetsky PA, Mitra N, Vardhanabhuti S, Li M, Vaughn DJ, et al: Common variation in KITLG and at $5 \mathrm{q} 31.3$ predisposes to testicular germ cell cancer. Nat Genet 41:811-815 (2009).

- Kehler J, Tolkunova E, Koschorz B, Pesce M, Gentile L, et al: Oct4 is required for primordial germ cell survival. EMBO Rep 5:10781083 (2004).

- Kersemaekers AM, Honecker F, Stoop H, Cools $\mathrm{M}$, Molier M, et al: Identification of germ cells at risk for neoplastic transformation in gonadoblastoma. Hum Pathol 36:512-521 (2005).

-Kim Y, Kobayashi A, Sekido R, DiNapoli L, Brennan J, et al: Fgf9 and Wnt4 act as antagonistic signals to regulate mammalian sex determination. PLoS Biol 4:e187 (2006).

Kobayashi A, Behringer RR: Developmental genetics of the female reproductive tract in mammals. Nat Rev Genet 4:969-980 (2003).

Kocer A, Reichmann J, Best D, Adams IR: Germ cell sex determination in mammals. Mol Hum Reprod 15:205-213 (2009).

Kohler B, Achermann JC: Update - steroidogenic factor 1 (SF-1, NR5A1). Minerva Endocrinol 35:73-86 (2010).

Koopman P, Gubbay J, Vivian N, Goodfellow P, Lovell-Badge R: Male development of chromosomally female mice transgenic for Sry. Nature 351:117-121 (1991).

Lau YF: Gonadoblastoma, testicular and prostate cancers, and the TSPY gene. Am J Hum Genet 64:921-927 (1999).

Lau Y, Chou P, Iezzoni J, Alonzo J, Komuves L: Expression of a candidate gene for the gonadoblastoma locus in gonadoblastoma and testicular seminoma. Cytogenet Cell Genet 91:160-164 (2000).
Li Y, Vilain E, Conte F, Rajpert-De Meyts E, Lau YF: Testis-specific protein Y-encoded gene is expressed in early and late stages of gonadoblastoma and testicular carcinoma in situ. Urol Oncol 25:141-146 (2007a).

Li Y, Tabatabai ZL, Lee TL, Hatakeyama S, Ohyama C, et al: The Y-encoded TSPY protein: a significant marker potentially plays a role in the pathogenesis of testicular germ cell tumors. Hum Pathol 38:1470-1481 (2007b).

Liao LM, Green H, Creighton SM, Crouch NS, Conway GS: Service users' experiences of obtaining and giving information about disorders of sex development. BJOG 117:193-199 (2010).

Lin L, Achermann JC: Steroidogenic factor-1 (SF-1, Ad4BP, NR5A1) and disorders of testis development. Sex Dev 2:200-209 (2008).

Looijenga LH, Stoop H, de Leeuw HP, de Gouveia Brazao CA, Gillis AJ, et al: POU5F1 (OCT3/4) identifies cells with pluripotent potential in human germ cell tumors. Cancer Res 63:2244-2250 (2003a).

- Looijenga LH, de Leeuw H, van Oorschot M, van Gurp RJ, Stoop H, et al: Stem cell factor receptor (c-KIT) codon 816 mutations predict development of bilateral testicular germ-cell tumors. Cancer Res 63:7674-7678 (2003b).

-Looijenga LH, Hersmus R, Oosterhuis JW, Cools M, Drop SL, Wolffenbuttel KP: Tumor risk in disorders of sex development (DSD). Best Pract Res Clin Endocrinol Metab 21:480495 (2007)

Looijenga LH, Hersmus R, de Leeuw BH, Stoop $\mathrm{H}$, Cools M, et al: Gonadal tumours and DSD. Best Pract Res Clin Endocrinol Metab 24:291-310 (2010).

-Lourenco D, Brauner R, Lin L, De Perdigo A, Weryha G, et al: Mutations in NR5A1 associated with ovarian insufficiency. N Engl J Med 360:1200-1210 (2009).

Loveland KL, Schlatt S: Stem cell factor and cKIT in the mammalian testis: lessons originating from Mother Nature's gene knockouts. J Endocrinol 153:337-344 (1997).

- Matin MM, Walsh JR, Gokhale PJ, Draper JS, Bahrami AR, et al: Specific knockdown of Oct4 and beta2-microglobulin expression by RNA interference in human embryonic stem cells and embryonic carcinoma cells. Stem Cells 22:659-668 (2004).

-Meduri G, Bachelot A, Duflos C, Bständig B, Poirot C, et al: FOXL2 mutations lead to different ovarian phenotypes in BPES patients: case report. Hum Reprod 25:235-243 (2010).

- Modi DN, Sane S, Bhartiya D: Accelerated germ cell apoptosis in sex chromosome aneuploid fetal human gonads. Mol Hum Reprod 9: 219-225 (2003).

Molyneaux K, Wylie C: Primordial germ cell migration. Int J Dev Biol 48:537-544 (2004).

Nakamura S, Aoki Y, Saito D, Kuroki Y, Fujiyama A, et al: Sox9b/sox9a2-EGFP transgenic medaka reveals the morphological reorganization of the gonads and a common precursor of both the female and male supporting cells. Mol Reprod Dev 75:472-476 (2008). 
Nef S, Vassalli JD: Complementary pathways in mammalian female sex determination. J Biol 8:74 (2009).

Niwa H, Miyazaki J, Smith AG: Quantitative expression of Oct-3/4 defines differentiation, dedifferentiation or self-renewal of ES cells. Nat Genet 24:372-376 (2000).

-Ogunbiyi JO, Shittu OB, Aghadiuno PU, Lawani $\mathrm{J}$ : Seminoma arising in cryptorchid testes in Nigerian males. East Afr Med J 73:129-132 (1996).

- Okamura D, Tokitake Y, Niwa H, Matsui Y: Requirement of Oct3/4 function for germ cell specification. Dev Biol 317:576-584 (2008).

-Oosterhuis JW, Looijenga LH: Testicular germcell tumours in a broader perspective. Nat Rev Cancer 5:210-222 (2005).

-Oram SW, Liu XX, Lee TL, Chan WY, Lau YF: TSPY potentiates cell proliferation and tumorigenesis by promoting cell cycle progression in HeLa and NIH3T3 cells. BMC Cancer 6:154 (2006).

-Ottolenghi C, Omari S, Garcia-Ortiz JE, Uda M, Crisponi L, et al: Foxl2 is required for commitment to ovary differentiation. Hum Mol Genet 14:2053-2062 (2005).

-Ottolenghi C, Uda M, Crisponi L, Omari S, Cao A, et al: Determination and stability of sex. Bioessays 29:15-25 (2007).

-Page DC: Hypothesis: a Y-chromosomal gene causes gonadoblastoma in dysgenetic gonads. Development 101:151-155 (1987).

- Parma P, Radi O, Vidal V, Chaboissier MC, Dellambra E, et al: R-spondin1 is essential in sex determination, skin differentiation and malignancy. Nat Genet 38:1304-1309 (2006).

- Pasterski V, Prentice P, Hughes IA: Impact of the consensus statement and the new DSD classification system. Best Pract Res Clin Endocrinol Metab 24:187-195 (2010).

- Pesce M, Wang X, Wolgemuth DJ, Scholer H: Differential expression of the Oct-4 transcription factor during mouse germ cell differentiation. Mech Dev 71:89-98 (1998).

-Piprek RP: Genetic mechanisms underlying male sex determination in mammals. J App Genet 50:347-360 (2009).

-Rajpert-De Meyts E, Skakkebaek NE: Expression of the c-KIT protein product in carcinoma-in-situ and invasive testicular germ cell tumours. Int J Androl 17:85-92 (1994).
Rajpert-De Meyts ER, Jorgensen N, Muller J, Skakkebaek NE: Prolonged expression of the c-KIT receptor in germ cells of intersex fetal testes. J Pathol 178:166-169 (1996).

Rajpert-De Meyts E, Jorgensen N, BrondumNielsen K, Muller J, Skakkebaek NE: Developmental arrest of germ cells in the pathogenesis of germ cell neoplasia. Apmis 106: 198-204 (1998).

Rajpert-De Meyts E, Hanstein R, Jorgensen N, Graem N, Vogt PH, Skakkebaek NE: Developmental expression of POU5F1 (OCT-3/4) in normal and dysgenetic human gonads. Hum Reprod 19:1338-1344 (2004).

Rapley EA, Turnbull C, Al Olama AA, Dermitzakis ET, Linger R, et al: A genome-wide association study of testicular germ cell tumor. Nat Genet 41:807-810 (2009).

-Schlessinger D, Garcia-Ortiz JE, Forabosco A, Uda M, Crisponi L, Pelosi E: Determination and stability of gonadal sex. J Androl 31:1625 (2010).

-Scully RE: Gonadoblastoma. A review of 74 cases. Cancer 25:1340-1356 (1970).

- Sekido R: SRY: a transcriptional activator of mammalian testis determination. Int J Biochem Cell Biol 42:417-420 (2010).

Sekido R, Lovell-Badge R: Sex determination involves synergistic action of SRY and SF1 on a specific Sox9 enhancer. Nature 453:930-934 (2008).

- Sekido R, Lovell-Badge R: Sex determination and SRY: down to a wink and a nudge? Trends Genet 25:19-29 (2009).

- Sharpe RM, McKinnell C, Kivlin C, Fisher JS: Proliferation and functional maturation of Sertoli cells, and their relevance to disorders of testis function in adulthood. Reproduction 125:769-784 (2003).

-Skakkebaek NE: Testicular dysgenesis syndrome: new epidemiological evidence. Int J Androl 27:189-191 (2004).

-Skakkebaek NE, Rajpert-De Meyts E, Jorgensen N, Main KM, Leffers H, et al: Testicular cancer trends as 'whistle blowers' of testicular developmental problems in populations. Int J Androl 30:198-204 (2007).

- Stoop H, Honecker F, Cools M, de Krijger R, Bokemeyer C, Looijenga LH: Differentiation and development of human female germ cells during prenatal gonadogenesis: an immunohistochemical study. Hum Reprod 20: 1466-1476 (2005).
Stoop H, Honecker F, van de Geijn GJ, Gillis AJ, Cools MC, et al: Stem cell factor as a novel diagnostic marker for early malignant germ cells. J Pathol 216:43-54 (2008).

Tannour-Louet M, Han S, Corbett ST, Louet JF, Yatsenko S, et al: Identification of de novo copy number variants associated with human disorders of sexual development. PloS One 5:e15392 (2010).

Tomaselli S, Megiorni F, De Bernardo C, Felici $A$, Marrocco G, et al: Syndromic true hermaphroditism due to an R-spondin 1 (RSPO1) homozygous mutation. Hum Mutat 29:220 226 (2008).

Uhlenhaut NH, Jakob S, Anlag K, Eisenberger T, Sekido R, et al: Somatic sex reprogramming of adult ovaries to testes by FOXL2 ablation. Cell 139:1130-1142 (2009).

van de Geijn GJ, Hersmus R, Looijenga LH: Recent developments in testicular germ cell tumor research. Birth Defects Res C Embryo Today 87:96-113 (2009).

-Verp MS, Simpson JL: Abnormal sexual differentiation and neoplasia. Cancer Genet Cytogenet 25:191-218 (1987).

-Virtanen HE, Cortes D, Rajpert-De Meyts E, Ritzén EM, Nordenskjöld A, et al: Development and descent of the testis in relation to cryptorchidism. Acta Paediatr 96:622-627 (2007).

-Wilhelm D, Koopman P: The makings of maleness: towards an integrated view of male sexual development. Nat Rev Genet 7:620-631 (2006).

Wilhelm D, Palmer S, Koopman P: Sex determination and gonadal development in mammals. Physiol Rev 87:1-28 (2007a).

-Wilhelm D, Hiramatsu R, Mizusaki H, Widjaja $\mathrm{L}$, Combes AN, et al: SOX9 regulates prostaglandin $\mathrm{D}$ synthase gene transcription in vivo to ensure testis development. J Biol Chem 282:10553-10560 (2007b).

Wilhelm D, Washburn LL, Truong V, Fellous M, Eicher EM, Koopman P: Antagonism of the testis- and ovary-determining pathways during ovotestis development in mice. Mech Dev 126:324-336 (2009). 